\title{
Intrauterine infusion of highly enriched bovine trophoblast protein-1 complex exerts an antiluteolytic effect to extend corpus luteum lifespan in cyclic cattle*
}

\author{
S. D. Helmer, P. J. Hansen, W. W. Thatcher, J. W. Johnson and \\ F. W. Bazer† \\ Departments of Dairy and $\dagger$ Animal Science, University of Florida, Gainesville, \\ Florida 32611-0701, USA
}

\begin{abstract}
Summary. Intrauterine infusion of enriched bovine trophoblast protein-1 complex (bTP-1) resulted in extension of interoestrous intervals and corpus luteum function in cyclic cattle. Conceptus proteins were obtained by culture of Day 17-18 conceptuses for $72 \mathrm{~h}$. Media from the first $(n=28)$, second $(n=26)$ and third $(n=19) 24 \mathrm{~h}$ of conceptus incubations were utilized. A highly enriched preparation of bTP-1 was obtained by a combination of ammonium sulphate precipitation, ion-exchange chromatography, and h.p.l.c. gel filtration. Degree of purity of the final preparation was confirmed by gel electrophoresis and immunoblotting with antiserum to ovine trophoblast protein- 1 . Jersey cattle ( 3 per group) received intrauterine infusions, twice daily from Day 15.5 to $21 \cdot 0$, of bovine serum albumin, the entire array of bovine conceptus secretory proteins (bCSP) from the 3 days of conceptus culture, or bTP-1. Infusions were via a catheter into the uterine horn ipsilateral to the corpus luteum. Oestrous cycle length in bTP-1-treated cows $(26 \cdot 1 \pm 1.3$ days) was greater than for cows given BSA (19.5 \pm 1.3 days) or bCSP (21.5 \pm 1.3 days). Similarly, progesterone concentrations in serum remained elevated for a longer period of time for bTP-1treated cows than for cows treated with BSA or bCSP. Residual variance associated with vena cava concentrations of PGF-2 $\alpha$ at Days 19-21 after oestrus (which included the variance between 15 -min periods within cows) was reduced in cows treated with bTP- 1 as compared to other groups. Lack of a bCSP effect may have been due to low amounts of bTP- 1 in conceptus-conditioned medium from cultures of $>24 \mathrm{~h}$. None the less, purified bTP-I was effective in extending luteal function and appears to be the antiluteolytic agent of early pregnancy.
\end{abstract}

Keywords: cattle; trophoblast protein-1; oestrous cycle; intrauterine infusion; corpus luteum; prostaglandins; luteolysis

\section{Introduction}

Continued maintenance of the corpus luteum (CL) is required if maintenance of early pregnancy is to occur in cattle. Failure of a conceptus to 'signal' its presence results in release of prostaglandin (PG) F-2 $\alpha$, luteolysis and resumption of ovarian cyclicity. The bovine conceptus must signal its presence by Day 15-17 of pregnancy if CL function is to be maintained (Northey \& French, 1980; Betteridge et al., 1984; Dalla Porta \& Humblot, 1984). Attenuation of PGF-2 $\alpha$ release and extension of CL lifespan are accomplished by secretion of conceptus secretory proteins (bCSP;

${ }^{*}$ Reprint requests: Dr William W. Thatcher. 
Knickerbocker et al., 1986a, b). The bovine trophoblast protein-1 complex (bTP-1), which represents a major component of bCSPs from Day-17-18 conceptuses (Bartol et al., 1985; Helmer et al., 1987), has been identified as a putative candidate for the antiluteolytic agent in cattle. Furthermore, bTP-1 is immunologically related to ovine trophoblast protein-1 (oTP-1; Helmer et al., 1987), which is responsible for luteal maintenance in the ewe (Godkin et al., 1984). The bTP-1 complex consists of 7 isoelectric variants ( $\mathrm{pI}=5.5$ to 5.7) of N-linked glycoproteins in two molecular weight classes; one of $M_{\mathrm{r}} 22000$ and high mannose content and the other of $M_{\mathrm{r}} 24000$ and complex carbohydrate content (Helmer et al., 1987, 1988; Anthony et al., 1988). The present study was designed to evaluate the role of bTP-1 in extension of CL lifespan by purifying bTP-1 and testing its efficacy as an antiluteolysin when infused into the uterine lumen during Days 15.5-21 of the oestrous cycle.

\section{Materials and Methods}

\section{Materials}

Tissue culture supplies were purchased from Grand Island Biological Co., Grand Island, NY, USA. A modified Eagle’s minimum essential medium (MEM, Gibco custom formula \$86-5007) was prepared according to procedures described previously (Malayer et al., 1988). L- $\left[{ }^{35} \mathrm{~S}\right]$ methionine (sp. act. $1300 \mathrm{Ci} / \mathrm{mmol}$ ) was from Amersham (Arlington Heights, IL, USA). Supplies for electrophoresis and $\mathrm{L}-\left[4,5-{ }^{3} \mathrm{H}\right] \mathrm{leucine}$ were obtained as described by Malayer et al. (1988). Urea (ultrapure) was obtained from Schwarz/Mann, Cambridge, MA, USA; ammonium sulphate was obtained from Serva, Heidelberg, NY, USA; Aquacide II was from Calbiochem, San Diego, CA, USA; pepstatin-A, leupeptin, phenylmethylsulphonyl fluoride (PMSF) and Nonidet P-40 were purchased from Sigma Chemical Co., St Louis, MO, USA; bovine albumin, Fraction V was from United States Biochemical Corp., Cleveland, OH, USA; carboxymethyl (CM)-Sepharose and DEAE Sepharose CL-6B were obtained from Pharmacia Fine Chemicals, Uppsala, Sweden; bicinchoninic acid (BCA) was from Pierce, Rockford, IL, USA. All other chemicals were reagent grade or better.

\section{In-vitro culture of conceptuses}

Conceptuses were collected from Angus and Brangus beef cows at Day 17-18 after oestrus (oestrus = Day 0 ) and were cultured as described previously (Helmer et al., 1987) for $72-96 \mathrm{~h}$, with medium being replaced every $24 \mathrm{~h}$. Cultures were carried out with either complete MEM, leucine-deficient $(\times 0 \cdot 1)$ MEM supplemented with $100 \mu \mathrm{Ci}\left[{ }^{3} \mathrm{H}\right.$ ] leucine/ culture $/ 24 \mathrm{~h}$, or in methionine-deficient $(\times 0 \cdot 1) \mathrm{MEM}$ supplemented with $100 \mu \mathrm{Ci}\left[{ }^{35} \mathrm{~S}\right]$ methionine/culture $/ 24 \mathrm{~h}$. Culture supernatants were frozen at $-20^{\circ} \mathrm{C}$ until utilized.

\section{Purification of bTP-1 complex}

Saturated ammonium sulphate precipitation of conceptus-conditioned culture medium. A total of 95 conceptus culture equivalents (the material harvested from a single conceptus culture during a 24-h incubation period) from the first $(n=36)$, second $(n=34)$ and third $(n=25) 24 \mathrm{~h}$ of culture were collected. Conceptus-conditioned culture medium was pooled $(\sim 1350 \mathrm{ml})$ and centrifuged for $15 \mathrm{~min}$ at $2600 \mathrm{~g}$ to remove particulate matter. From this pool, fluid representing 22 culture equivalents was set aside for infusion into cows receiving the bCSP treatment. The bCSP $(30 \mathrm{ml})$ from conceptuses cultured in the presence of $\left[{ }^{3} \mathrm{H}\right]$ leucine $\left(2 \mathrm{I} \times 10^{6}\right.$ d.p.m. radioactivity) were added to the remaining 73 culture equivalents to monitor subsequent yields during purification. An equal volume of saturated ammonium sulphate (SAS) was added to the medium, incubated for $2 \mathrm{~h}$ at $4^{\circ} \mathrm{C}$, and centrifuged $(13000 \mathrm{~g})$ for $30 \mathrm{~min}$. After harvesting the supernatant, precipitates were resuspended in $20 \mathrm{ml} 20 \mathrm{~mm}$-Tris- $\mathrm{HCl} \mathrm{pH} 8.2$ and the SAS precipitation procedure repeated. Supernatants from the second procedure were pooled with supernatants from the original precipitation. This material was buffered with $10 \mathrm{~mm}$-acetate $\mathrm{pH} 5.0$ containing $1 \mathrm{~mm}$-ethylene-diaminetetraacetic acid (EDTA), $0.7 \mathrm{mg}$ pepstatin-A/1, $0.5 \mathrm{mg}$ leupeptin $/ 1$ and $0.02 \%(\mathrm{w} / \mathrm{v}) \mathrm{NaN}_{3}$ and dialysed $\left(M_{\mathrm{r}}\right.$ cut-off $\left.=6000-8000\right)$ against 8 changes of 4 -litre volumes of $10 \mathrm{mM}$-acetate buffer (pH 5.0) containing $1 \mathrm{mM}$-EDTA, $0.2 \mathrm{mM}$-PMSF, $0.7 \mathrm{mg}$ pepstatin-A/l and $0.02 \% \mathrm{NaN}_{3}$. Supernatants were dialysed further against two changes of 6-litre volumes of $20 \mathrm{~mm}-$ Tris- $\mathrm{HCl}$ pH 8.2 with $1 \mathrm{~mm}$-EDTA, $0.7 \mathrm{mg}$ pepstatin-A $/ 1,0.5 \mathrm{mg}$ leupeptin/l and $0.02 \% \mathrm{NaN}_{3}$. After dialysis, the material was adjusted to a $\mathrm{pH}$ of 8.2 by addition of $1 \mathrm{M}-\mathrm{NaOH}$ in preparation for CM-Sepharose column chromatography. Because of the influx of water due to osmotic pressure differences in initial dialysis steps, volume of the material was approximately doubled during the dialysis process.

Ion exchange chromatography. All buffers used for ion exchange chromatography contained a cocktail of protease and bacterial growth inhibitors composed of $1 \mathrm{~mm}$-EDTA, $0.7 \mathrm{mg}$ pepstatin-A/l, $0.5 \mathrm{mg}$ leupeptin/l, and $0.02 \%$ (w/v) 
$\mathrm{NaN}_{3}$. Supernatants from SAS precipitation were passed over a $2.6 \mathrm{~cm} \times 3.6 \mathrm{~cm}$ CM-Sepharose column equilibrated in $20 \mathrm{~mm}$-Tris- $\mathrm{HCl} \mathrm{pH} \mathrm{8.2.} \mathrm{Bound} \mathrm{proteins} \mathrm{were} \mathrm{eluted} \mathrm{subsequently} \mathrm{using} 20 \mathrm{~mm}$-Tris- $\mathrm{HCl} \mathrm{pH} 8 \cdot 2$ containing $1 \mathrm{M}-$ $\mathrm{NaCl}$. Material not binding to the column was further processed by passage through two DEAE columns $(2.6 \mathrm{~cm} \times 3.6 \mathrm{~cm})$ pre-equilibrated with $10 \mathrm{~mm}$-Tris $\mathrm{pH} 8.2$ and attached in series. After washing extensively with $20 \mathrm{~mm}$-Tris- $\mathrm{HCl} \mathrm{pH} \mathrm{8} \cdot 2$, bound proteins were eluted from each of the two DEAE columns separately, using $0 \cdot 2 \mathrm{M}$ sodium phosphate buffer $\mathrm{pH} 7 \cdot 9$. First, one column volume of buffer was run through each column and flow stopped for a period of $2 \mathrm{~h}$. Column flow was then continued and fractions pooled based upon presence of radioactivity. Pooled fractions were concentrated from $161 \mathrm{ml}$ to $22.7 \mathrm{ml}$ in a period of $24 \mathrm{~h}$ by placing the sample in dialysis tubing ( $M_{\mathrm{r}}$ cut-off $=3500$ ) and packing the tubing in Aquacide II (carboxymethyl cellulose) to remove the buffer. Samples of $1 \mathrm{ml}$ were stored at $-70^{\circ} \mathrm{C}$ until separation by h.p.l.c. gel filtration.

High-pressure liquid chromatography. To minimize ionic interaction with the Zorbax GF-250 gel filtration column, samples were always prepared with sodium phosphate at a concentration of at least $0.2 \mathrm{M}$. This buffer was designed to reduce ionic interactions with hydroxyl groups on the silica based h.p.l.c. column, while utilizing a biologically compatible buffer to preserve sample integrity. To maintain the minimum $0.2 \mathrm{M}$-phosphate concentration, solid sodium phosphate (monobasic $=0.082 \mathrm{~g} / 100 \mathrm{ml}$; dibasic $=1.370 \mathrm{~g} / 100 \mathrm{ml}$ ) was added to the concentrated samples and $\mathrm{pH}$ was adjusted to 7.9. Addition of sodium phosphate was necessary to correct for dilution of phosphate buffer that might have occurred during the anion-exchange step. In addition, it was found that non-specific binding of protein could be reduced from approximately $60 \%$ to $25 \%$ with a preliminary coating of the column with $1 \mathrm{mg}$ BSA. Separation by h.p.l.c. was achieved using a system consisting of a Series 4 Liquid Chromatograph Microprocessor Controlled Solvent Delivery System (Perkin-Elmer; Norwalk, CT, USA), a Series 4 Control Module to control the delivery system (Perkin-Elmer), an ISS-100 Intelligent Sampling System with refrigerated sample tray (PerkinElmer), a Zorbax GF-250 gel filtration column (DuPont Co.; Wilmington, DE, USA), an LKB 2I 40 Rapid Spectral Detector (LKB; Bromma, Sweden), and LKB 2211 SupeRac fraction collecting system custom modified to include a refrigerated collection tray. Elution profiles for separation of proteins were analysed using LKB Wavescan software on an IBM XT computer connected to the spectral detector. The mobile phase was $0.2 \mathrm{M}$-sodium phosphate buffer $\mathrm{pH} 7.9$ with a flow rate of $0.7 \mathrm{ml} / \mathrm{min}$. Aliquants of the sample $(175 \mu \mathrm{l})$ were passed over the h.p.l.c. gel filtration column and 4-drop fractions $(230 \mu \mathrm{l})$ were collected. Injections completed during the course of 1 day were collected into one set of fraction receptacles $(5 \mathrm{ml})$ maintained at $4^{\circ} \mathrm{C}$. At the end of each daily collection period, fractions were frozen. Once all of the samples had been processed in this fashion, fractions corresponding to elution volumes of protein having molecular weights of $\sim 20000-29000$ were pooled.

Confirmation of purity. Aliquants of bovine serum albumin (BSA; $20 \mu \mathrm{g})$, bCSP $(100 \mu \mathrm{g})$ and purified bTP-1 $(16 \mu \mathrm{g})$ were concentrated and desalted using AMICON 10 ultrafiltration devices (AMICON, Danvers, MA, USA) and evaluated for purity using two dimension SDS-polyacrylamide gel electrophoresis (2-D SDS-PAGE). Proteins in the gels were identified by silver staining (Wray et al., 1981). Immunoblotting was also carried out to identify immunoreactive bTP-1 in the purified array of proteins. Purified bTP-1 complex was separated by 2-D SDS-PAGE $(8 \mu \mathrm{g} / \mathrm{gel})$ and electrophoretically transferred to nitrocellulose $(0.2 \mu \mathrm{m}$; Schleicher \& Schuell, Keene, NH, USA). Blots were stained for $5 \mathrm{~min}$ to identify protein standards using $0.05 \%(\mathrm{w} / \mathrm{v})$ amido black in methanol:acetic acid:water (40: 10:50, by vol.) and destained for $2 \mathrm{~min}$ in the same solvent. Blots were then washed briefly with water and placed in blocking buffer ( $10 \mathrm{~mm}$-Tris-HCl pH 7.4 containing $2 \%$ (w/v) gelatin, $0.15 \mathrm{M}-\mathrm{NaCl}, 0.01 \%(\mathrm{v} / \mathrm{v})$ Tween 20 and $0.02 \%$ (w/v) sodium azide) for $8 \mathrm{~h}$. Subsequently, blots were incubated for $2 \mathrm{~h}$ with rabbit antiserum to oTP-1 (diluted 1:100) or normal rabbit serum (NRS; diluted 1:100). Both sera were diluted in incubation buffer (10 mM-Tris- $\mathrm{HCl}$ pH 7.4 containing $1 \%(\mathrm{w} / \mathrm{v})$ gelatin, $0.15 \mathrm{M}-\mathrm{NaCl}, 0.01 \%(\mathrm{v} / \mathrm{v})$ Tween 20 and $0.02 \%(\mathrm{w} / \mathrm{v})$ sodium azide). Blots were rinsed with water, washed in incubation buffer twice for $30 \mathrm{~min}$ and then incubated with $20 \mathrm{ml}{ }^{125}$ I-labelled Protein A $\left(1 \times 10^{6}\right.$ c.p.m./ml incubation buffer; prepared as described by Hansen \& Newton, 1988) for $1 \mathrm{~h}$. Blots were then washed extensively with incubation buffer and allowed to dry. Autoradiography was then performed using Kodak XAR-film and enhancing screens for visualization of immunoreactive protein bands.

\section{Other procedures}

Polyacrylamide gel electrophoresis. One-dimensional and two-dimensional sodium dodecyl sulphate polyacrylamide gel electrophoresis (1-D and 2-D SDS-PAGE), were performed as described elsewhere (Laemmli, 1970; Roberts et al., 1984; Malayer et al., 1988).

Protein determination. Protein concentrations were determined by the BCA protein assay using BSA as the standard (Smith et al., 1985).

Preparation of materials for intrauterine infusion. All materials were prepared in $0.2 \mathrm{M}-\mathrm{NaPO}_{4}$ buffer $\mathrm{pH} 7.4$ with added penicillin $(100 \mathrm{U} / \mathrm{ml})$ and streptomycin $(100 \mu \mathrm{g} / \mathrm{ml})$. Bovine serum albumin was prepared at a concentration of $1.5 \mathrm{mg}$ per $2.13 \mathrm{ml}$ for infusion. Bovine conceptus proteins ( $n=22$ culture equivalents) were dialysed extensively against $10 \mathrm{mM}-\mathrm{NaPO}_{4} \mathrm{pH} 7 \cdot 4$ containing penicillin/streptomycin and then concentrated as described previously using Aquacide II. Sodium phosphate (to a concentration of $0.2 \mathrm{M}$ ), BSA and penicillin/streptomycin were added to the concentrate and $\mathrm{pH}$ adjusted to 7.4 . Infusion doses for bCSP contained $0.75 \mathrm{mg}$ bCSP and $0.75 \mathrm{mg}$ BSA in a volume of $2.13 \mathrm{ml}$. Purified bTP-1 was prepared as a solution of $35 \mu \mathrm{g}$ bTP- 1 and $1.465 \mathrm{mg}$ BSA in $2.13 \mathrm{ml}$. The BSA was added as a carrier for bTP-1 to approximate total protein mass produced during a $24 \mathrm{~h}$ period by a conceptus 
(Knickerbocker et al., 1986b), to provide a protein pool to minimize destruction of bTP-1 by endogenous uterine proteases, and to provide a carrier molecule comparable to that used in the BSA control group. All samples were frozen at $-70^{\circ} \mathrm{C}$ until time of intrauterine infusion.

Animal preparations. Cyclic, non-lactating Jersey cows $(\mathrm{N}=9)$ were assigned randomly to BSA (control), bCSP or bTP-1 treatment groups and prepared for surgical placement of uterine catheters as described by Knickerbocker $e t$ al. $(1986 \mathrm{~b})$ on Day $11(\mathrm{~N}=3)$ or Day $12(\mathrm{~N}=6)$ of the oestrous cycle. Treatments were randomized with day of oestrous cycle on which surgery was performed.

Intrauterine infusions, into the uterine horn ipsilateral to the $\mathrm{CL}$, were administered at $12-\mathrm{h}$ intervals (1.5 mg protein per infusion) from 19:00 h on Day 15 to 07:00 h on Day 21. Blood was collected via jugular venepuncture every other day from Days 7 to 13 . On Day 15, all cows were fitted with an indwelling jugular catheter (V-9; Bolab Incorporated). Blood samples were collected twice daily $(07: 30$ and 19:30 h) into heparinized tubes from Day 15 until $24 \mathrm{~h}$ after onset of oestrus and plasma was harvested after centrifugation $\left(20 \mathrm{~min}, 1200 \mathrm{~g}, 4^{\circ} \mathrm{C}\right)$.

Polyethylene catheters $(120 \mathrm{~cm}$; i.d. $0.86 \mathrm{~mm}, 0 . \mathrm{d} .1 .27 \mathrm{~mm})$ also were placed into the posterior vena cava immediately anterior to the uterine drainage on Day 18 of the oestrous cycle by a modification of the procedure described by Sears et al. (1978). Blood samples $(10 \mathrm{ml})$ were taken every $15 \mathrm{~min}$ from 09:00 h to 15:00 h on Days 19, 20 and 21 of the oestrous cycle. Sample collections were discontinued before Day 21 if a cow was observed in oestrus. Samples were placed in an ice bath, centrifuged $\left(20 \mathrm{~min}, 1200 \mathrm{~g}, 4^{\circ} \mathrm{C}\right)$ within $15 \mathrm{~min}$ of collection, and plasma frozen.

Animals were maintained in a concrete pen from Day 7 of the oestrous cycle until surgery was performed. Animals were then housed in stanchions for duration of the experiment. Paint was applied to the tail head of all cows and crayon applied over this to facilitate detection of oestrus (Macmillan et al., 1988). Cows were allowed access to dirt lot twice daily (08:00 and 20:00 h) for $30 \mathrm{~min}$ from Day 15 until $24 \mathrm{~h}$ after the last animal was detected in oestrus for observation of oestrus. At this time, all intrauterine catheters were cleaned, withdrawn from the body cavity as far as possible by gentle traction, cut and allowed to pass into the body cavity. Animals were then maintained on pasture until observed in oestrus.

Radioimmunoassay of plasma hormones. Progesterone concentrations in heparinized plasma samples were measured with an assay system described by Knickerbocker et al. (1986b). With antiserum dilution of 1:40 000, sensitivity of the assay ( 100 or $200 \mu$ l samples) was $31.2 \mathrm{pg}$ per tube. Intra- and interassay coefficients of variation were $7 \cdot 11 \%$ and $13 \cdot 41 \%$, respectively.

Heparinized plasma samples from the posterior vena cava were assayed for PGF by procedures described by Knickerbocker et al. (1986c) for unextracted samples. The assay was modified to use an antibody supplied and characterized by Kennedy (1985); cross-reactivities of the PGF- $2 \alpha$ antiserum were described previously by Gross $e t$ al. (1988b). Cross-reactivity of the PGF-2 $\alpha$ antiserum for PGF-1 $\alpha$ was $94 \%$, and so results of assays performed with this antiserum are referred to as PGF activity. Unextracted plasma samples of $200 \mu l$ were assayed for PGF. Sensitivity of the assay procedure was $10 \mathrm{pg}$ (i.e. $50 \mathrm{pg} / \mathrm{ml}$ ) with an antibody dilution of 1:5000. Accuracy of the procedure for unextracted plasma was characterized by measuring known quantities of exogenous PGF added to $200 \mu \mathrm{l}$ plasma (from cattle treated with an inhibitor to cyclo-oxygenase; Guilbault et al., 1984) at concentrations of $10-5000 \mathrm{pg}$ per tube $[y=18 \cdot 0+1.06 x ; y=$ amount of PGF measured $(\mathrm{pg} / 0.2 \mathrm{ml})$, and $x=$ amount of PGF added $(\mathrm{pg} / 0 \cdot 2 \mathrm{ml}), \mathrm{R}^{2}=0.98$ ]. A quantitative linear displacement curve was achieved. Tests for homogeneity of regression between this curve and the standard curve indicated that the curves were parallel. The intra- and interassay coefficients of variation were $10 \cdot 6 \%$ and $18 \cdot 5 \%$, respectively.

\section{Statistical analysis}

Data for progesterone concentrations in plasma were analysed using the General Linear Models procedure of the Statistical Analysis System (SAS Institute Incorporated, 1985) for a split-plot analysis of variance with repeated measurements over time. The analysis of variance considered variability due to treatment (bTP-1, bCSP and BSA), cow nested within treatment, sample time, treatment by time interaction and residual. To provide further estimates of temporal changes, progesterone concentrations were analysed by least squares regression analyses, and differences in treatment means and regression curves were evaluated by orthogonal contrasts (BSA vs bCSP and bTP-1; bCSP vs bTP-1). For example, differences in polynomial regression curves were tested by examining for homogeneity of regression between treatment response curves. These data were analysed with time as a continuous, independent variable. Data pertaining to interoestrous interval during the treatment oestrous cycle, period from pre-treatment oestrus until when progesterone fell below $1 \mathrm{ng} / \mathrm{ml}$, period from when progesterone fell below $1 \mathrm{ng} / \mathrm{ml}$ to subsequent oestrus, and post-treatment interoestrous interval were analysed by least squares analysis of variance. Differences between treatment means were evaluated by orthogonal contrasts already described above.

Data pertaining to plasma PGF concentrations were evaluated by analysis of variance with treatment, cow nested within treatment, and residual considered in the model. Day was not considered due to the unbalanced distribution of cows among days. For Day 19, 2 BSA, 2 bCSP, and 2 bTP-1 cows were represented. Of these cows, on Day 20, 1 BSA and 2 bTP- 1 cows were represented, and on Day 21 , only the 2 bTP-1 cows were represented. Analysis of the data indicated that variances among treatment groups were heterogeneous. Data were therefore transformed for analysis by taking the reciprocal of PGF concentration and differences for treatment means examined. 


\section{Results}

Characteristics of the culture system

Conceptus culture supernatants from the first, second, third, and fourth 24-h culture periods $(n=3)$ were analysed for incorporation of radiolabel into non-dialysable molecules and protein content (Table 1). Incorporation of radiolabel into non-dialysable secreted proteins and protein content in culture supernatants tended to increase from the first to second 24-h culture period, remained constant through the 3 rd day of culture and declined during the 4 th day of culture.

Table 1. Percentage incorporation of $\left[{ }^{3} \mathrm{H}\right]$ leucine into non-dialysable protein and protein content in culture supernatants obtained after the first, second, third and fourth $24 \mathrm{~h}$ of conceptus culture*

\begin{tabular}{lccc}
\hline $\begin{array}{l}\text { Culture } \\
\text { period }\end{array}$ & $n$ & $\begin{array}{c}\% \\
\text { Incorporation }\end{array}$ & $\begin{array}{c}\text { Protein } \\
\text { content }(\mathrm{mg})\end{array}$ \\
\hline First & 3 & $17.28 \pm 11.67$ & $2.16 \pm 0.62$ \\
Second & 2 & $49.66 \pm 27.70$ & $4.05 \pm 2.17$ \\
Third & 3 & $52.22 \pm 20.50$ & $3.03 \pm 2.85$ \\
Fourth & 3 & $13.02 \pm 17.62$ & $1.71 \pm 0.15$ \\
\hline
\end{tabular}

*Values are mean \pm s.e.m.; $n=$ number of cultures.

Samples from one conceptus were analysed to evaluate qualitative patterns of nondialysable radiolabelled macromolecules as determined by h.p.l.c. gel filtration chromatography (Fig. 1). Profiles of proteins present during the consecutive culture periods were similar for all days of culture. Of immediate interest is the fact that bTP-1, which migrated approximately in Fractions 42-44, did not represent the major conceptus product as observed in polyacrylamide gels. This is unlike the results when conceptus secretory proteins are analysed by SDS-PAGE (see Fig. 4). The proportion of counts recovered from Fractions 41-45 (corresponding to where bTP-1 elutes) ranged from 20 to $22 \%$, while low-molecular weight products (Fractions 46-50) comprised 22-28\% of the radioactivity. The discrepancy between h.p.l.c. and electrophoretic analysis probably reflects the fact that the low molecular-weight products are lost during fixation steps of electrophoresis.

\section{Purification}

It was determined in preliminary experiments that bTP-1 is extremely sensitive to proteolytic cleavage. As monitored by h.p.l.c. gel filtration, radiolabelled proteins in fractions corresponding to bTP-1 complex decreased when conceptus culture supernatants were stored for several days at $4^{\circ} \mathrm{C}$ (data not shown). A mixture of protease inhibitors containing $1 \mathrm{~mm}$-EDTA, $0.7 \mathrm{mg}$ pepstatin$\mathrm{A} / 1$ and either $0.5 \mathrm{mg}$ leupeptin/ 1 or $0.2 \mathrm{~mm}$-PMSF was effective in inhibiting proteolytic cleavage of proteins during storage and purification procedures carried out at $4^{\circ} \mathrm{C}$.

The first step of the purification procedure was saturated ammonium sulphate (SAS) precipitation of proteins. Adding SAS to a final concentration of $50 \%(\mathrm{v} / \mathrm{v})$ resulted in a majority of the bTP-1 complex remaining in solution while several other proteins, including some with molecular weights similar to bTP-1, were precipitated (Fig. 2). The process of SAS fractionation and subsequent dialysis resulted in about a 4-fold increase in volume compared to the starting volume. Supernatant was passed over a CM-Sepharose column equilibrated at a $\mathrm{pH}$ of 8.2 to remove basic proteins ( $\mathrm{pI}>8 \cdot 2$ ). Anion-exchange chromatography was then performed utilizing a DEAE column at $\mathrm{pH} 8.2$ to concentrate the acidic protein fraction. Bound material was eluted with $0 \cdot 2 \mathrm{M}$ sodium phosphate buffer, $\mathrm{pH} 7 \cdot 9$, in a small volume and fractions concentrated further by placing 


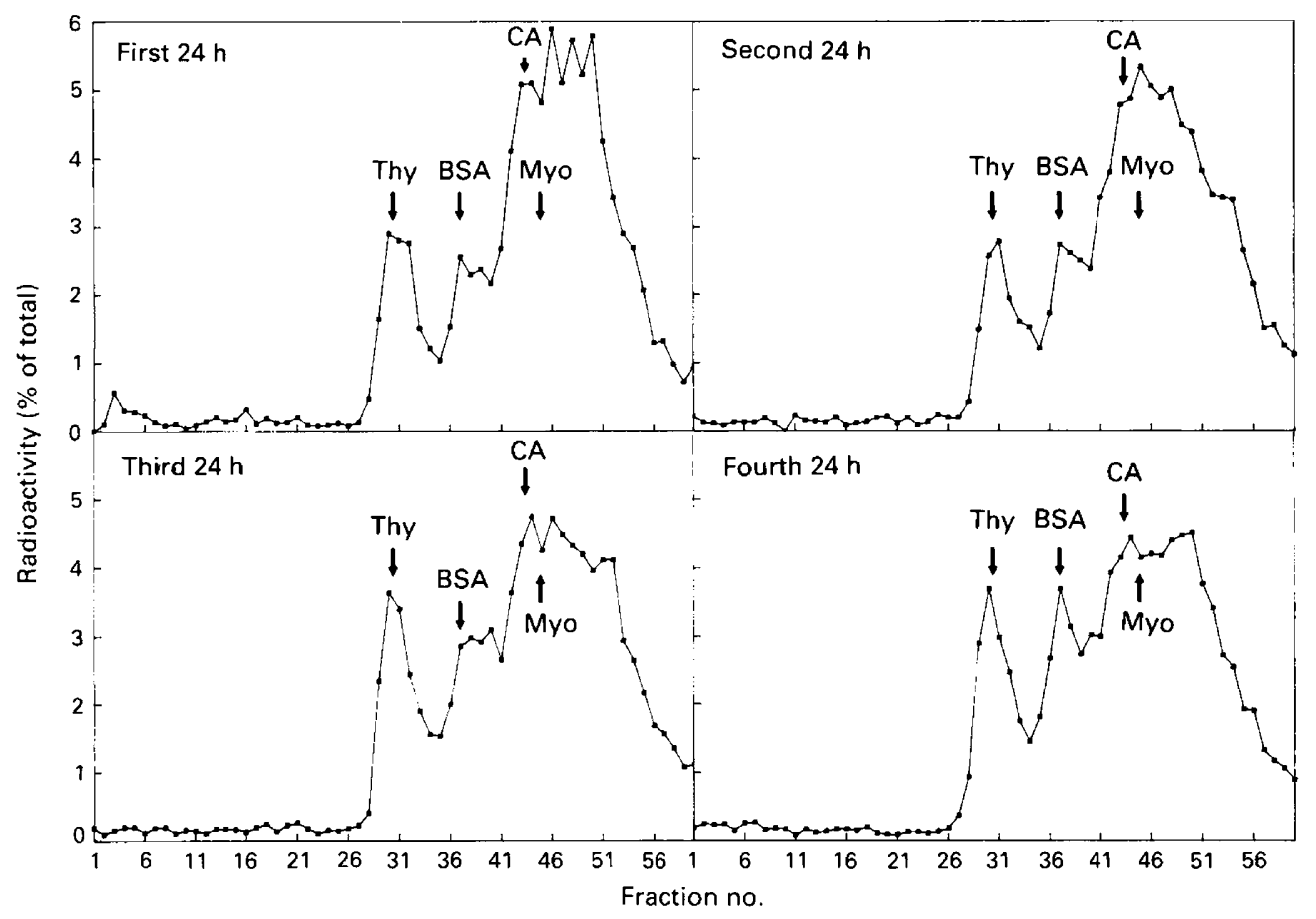

Fig. 1. The h.p.l.c. gel filtration profiles of radiolabelled conceptus conditioned medium from the $1 \mathrm{st}, 2 \mathrm{nd}, 3 \mathrm{rd}$ and 4 th days of culture of a conceptus. Culture was performed in the presence of $\left[{ }^{3} \mathrm{H}\right]$ leucine. Conceptus supernatants were centrifuged $\left(2600 \mathrm{~g}, 4^{\circ} \mathrm{C}\right)$ for $30 \mathrm{~min}$ to remove particulate matter and dialysed extensively $\left(M_{\mathrm{r}}\right.$ cut-off $\left.=3500\right)$. Aliquants of medium containing $\sim 25000$ d.p.m. $\left[{ }^{3} \mathrm{H}\right]$ leucine were injected onto a Zorbax GF-250 h.p.l.c. gel filtration column to resolve proteins. Data on radioactivity are expressed as a percentage of the total radioactivity loaded onto the column. Thy $=$ thyroglobulin; BSA $=$ bovine serum albumin; Myo = myoglobin; $\mathrm{CA}=$ carbonic anhydrase.

the material in dialysis tubing packed in Aquacide II. The resulting material was separated by h.p.l.c. gel filtration in $0 \cdot 2 \mathrm{M}-\mathrm{NaPO}_{4} \mathrm{pH} \mathrm{7.9}$. Pooling of fractions was carried out after determining distribution of methionine-radiolabelled bTP-1 complex and other proteins by 1-D SDS-PAGE of individual fractions (Fig. 3). The region corresponding to bTP-1 (Fractions 46-48) also contained a protein species at an $M_{\mathrm{r}}$ of $\sim 45000$. The bTP-1 complex generally eluted in 3-5 fractions and 3-4 of these were pooled for preparing infusates.

\section{Purity and yield of bTP-1}

A total of $1.5 \mathrm{mg}$ purified bTP-1 was obtained through the processing of 73 culture equivalents containing $138.7 \mathrm{mg}$ total protein. This represents a yield of $1.1 \%$ (i.e. $20 \mu \mathrm{g}$ bTP-1 per culture equivalent). Purity of bTP-1 was assessed by 2-D SDS-PAGE and silver staining (Fig. 4). Ten protein species could be visualized (Fig. 4a) including three at $M_{\mathrm{r}} 22000,5$ at $M_{\mathrm{r}} 24000$ and 2 at $M_{\mathrm{r}}$ 26000. This compares closely with results of Helmer et al. (1987) in which the immunologically reactive components of the bTP-1 complex were first described. As shown in Fig. 4(b) and elsewhere (Dunbar, 1987), components of the sample loading buffer stained with silver; to ascertain purity of bTP-1, it was therefore necessary to compare electrophoretograms of bTP-1 with those of loading buffer only. The only protein species detected by silver staining in the purified bTP-1 preparation that was not the result of non-specific staining was a minor contaminant migrating as 


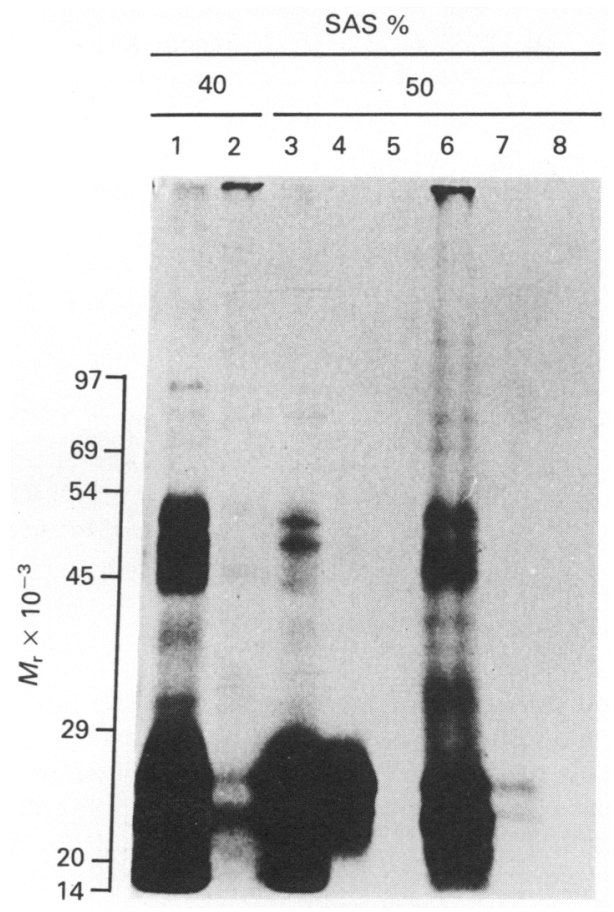

Fig. 2. Fluorograph of electrophoretogram of bCSPs subjected to 40 or $50 \%$ saturated ammonium sulphate (SAS) precipitation. Lanes 1, 3, 4 and 5 represent material from bCSP found in the supernatant and Lanes 2, 6, 7 and 8 material in the precipitate. Total material found in supernatant (Lanes 1 and 3) and precipitates (Lanes 2 and 6) is shown. Supernatants and precipitates were immunoabsorbed with rabbit anti-oTP-1 antiserum (Lanes 4 and 7) or normal rabbit serum (Lanes 5 and 8).

BSA (compare Fig. $4 \mathrm{a}$ to $4 \mathrm{~b}$ which represents a 2-D gel containing no protein). This may represent potential leaching of BSA from the pre-coated Zorbax GF 250 column. The bTP-1 preparation is designated as highly enriched bTP-1 due to the presence of BSA. Proteins present in the preparations of bCSP and BSA used for infusion are shown in Fig. 4 (c, d).

Immunoblotting using anti-oTP-1 antiserum was performed to verify that the purified proteins were in fact bTP-1 (Fig. 5). The array of proteins that cross-reacted with the antibody corresponded exactly with those identified by silver staining in the purified bTP-1 preparation (Fig. 4a) except that BSA did not react. More isoelectric species of the bTP-1 were identified as being immunoreactive in this study than those reported earlier (Helmer et al., 1987). This may be due to enrichment of bTP-1 molecular components during purification that were not detectable by immunoprecipitation of bCSP as described earlier (Helmer et al., 1987).

\section{Effects of intrauterine infusions on oestrous cycle responses}

Treatment of cyclic cows with highly enriched bTP-1 extended the interoestrous interval (Table 2). Orthogonal contrasts were made comparing (1) BSA vs bCSP and bTP-1 treatment and (2) bCSP $v s$ bTP-1 treatment for all responses. Interoestrous interval in which treatments were administered was greater $(P<0.04)$ for cows treated with bCSP and bTP-1 than for BSA-treated cows. The increase was due to a longer interoestrous interval for bTP-1-treated cows than for cows treated with bCSP $(P<0.05)$ or for BSA-treated cows. 


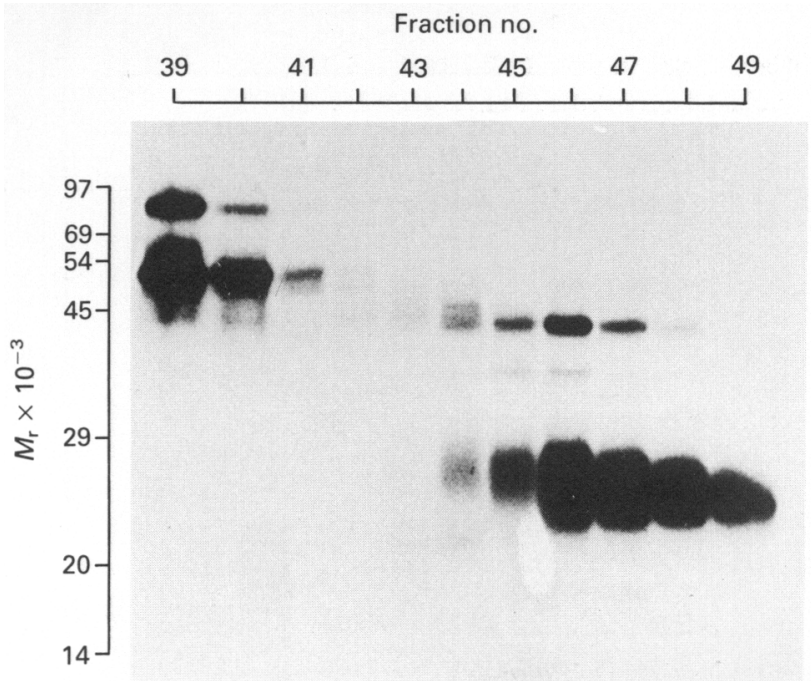

Fig. 3. Fluorograph of an electrophoretogram of conceptus secretory proteins after separation by h.p.l.c. gel filtration. Conceptus proteins were obtained from the culture of Day 17-18 conceptuses incubated in the presence of $100 \mu \mathrm{Ci}\left[{ }^{35}\right.$ S]methionine for $24 \mathrm{~h}$. Starting material for h.p.l.c. was bCSP that had been subjected to SAS precipitation and ion exchange chromatography. Fractions represent pools of 15 single injections ( $20 \mathrm{sec}$ per fraction) which were subsequently dialysed, lyophilized and separated by l-D SDS-PAGE.

\section{Progesterone profiles}

Differences in CL lifespan between groups was examined by evaluating plasma progesterone profiles through a regression analysis that allowed treatment differences to be tested by homogeneity of regression analysis (Knickerbocker et al., 1986b). Luteal phases were extended for bCSP and bTP-1 treatments compared to BSA-treated controls $(P<0 \cdot 01 ;$ Fig. 6). This difference was due largely to an extension of the luteal phase of bTP-1-treated cows since these cows differed from bCSP-treated animals $(P<0.01)$.

Orthogonal contrasts comparing the interval from the pre-treatment oestrus to when progesterone fell below $1 \mathrm{ng} / \mathrm{ml}$ was greater $(P<0 \cdot 1)$ for bCSP- and bTP-1 - vs BSA-treated animals $(18.5$ and 24.0 vs 17.7 days, respectively); the interval was longer $(P<0.02)$ for cows treated with bTP-1 than for cows treated with bCSP. The period between when progesterone fell below $1 \mathrm{ng} / \mathrm{ml}$ and the post-treatment oestrus was not different between treatments (Table 2). Similarly, post-treatment oestrous cycle lengths were not affected by treatments (Table 2).

\section{Prostaglandin profiles}

Due to difficulties encountered with inserting and maintaining vena cava catheters, only 2 cows from each treatment group were sampled successfully. Components of variation in residual variances for each treatment include experimental error, but also sample to sample variation among the consecutive 2515 -min periods within and among the days for each of the cows. Residual variances for bTP-1-treated cows (192.02) were lower than for bCSP-treated cows (326.42) and BSA-treated cows (7199.08). This was apparent when examining individual profiles of cows sampled on each day. The BSA-treated cows exhibited frequent elevations of plasma PGF concentrations, whereas most samples for bTP-1- and bCSP-treated animals were undetectable in the radioimmunoassay (Fig. 7). Due to heterogeneity of variances, data were transformed before statistical analysis by using the reciprocal of PGF values. Transformation reduced heterogeneity of variances, but variances were still significantly different $(P<0 \cdot 05)$. Analysis of variance to test 


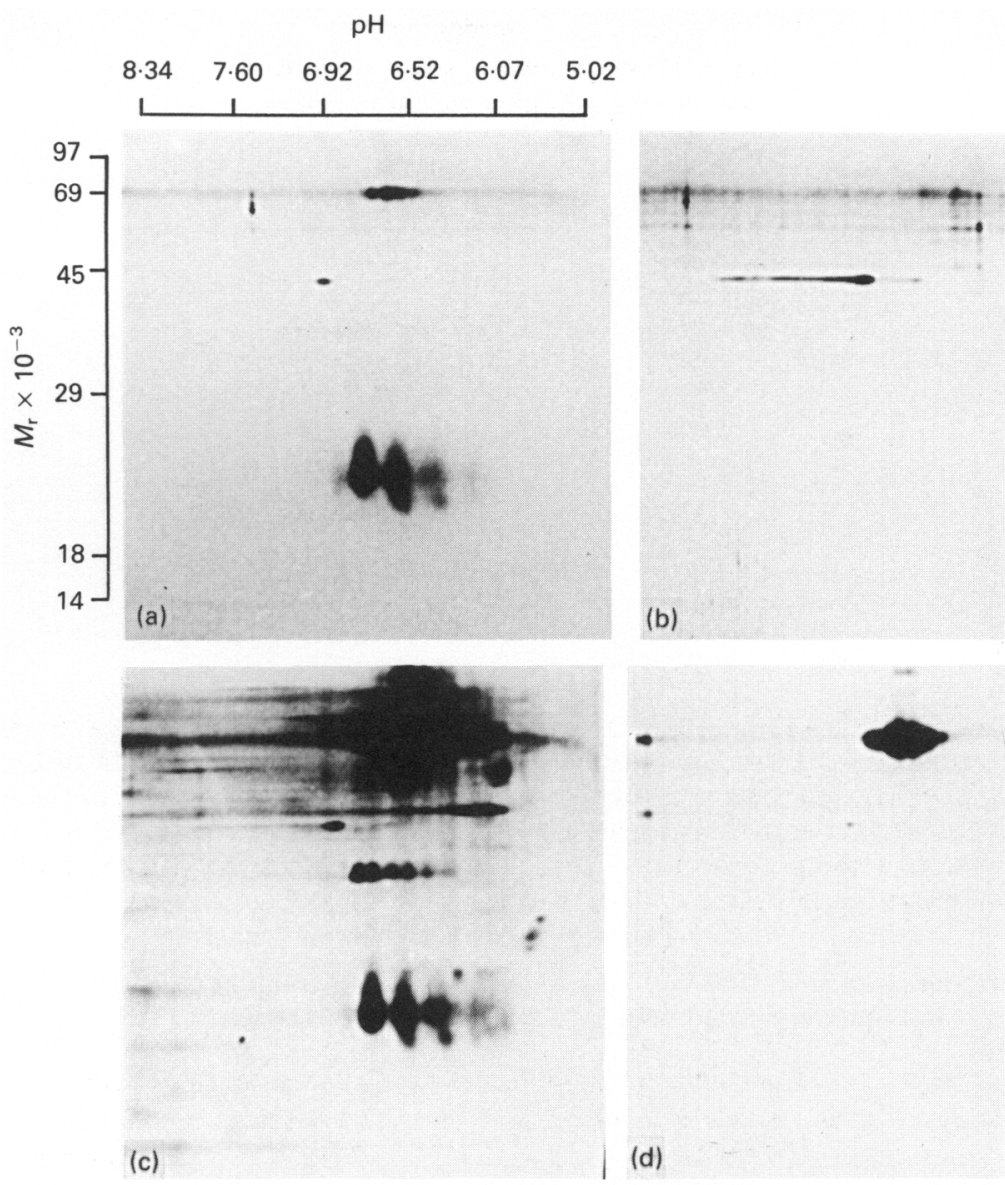

Fig. 4. Silver-stained, two-dimensional electrophoretograms of (a) highly enriched bTP-1 complex $(16 \mu \mathrm{g})$, (b) sample buffer without protein, (c) total conceptus proteins (100 $\mu \mathrm{g})$ and (d) bovine serum albumin $(20 \mu \mathrm{g})$.

treatment means (PGF) indicated that the BSA $(97 \cdot 1 \pm 9.79 \mathrm{ng} / \mathrm{ml})$ versus bTP-1 $(53.3 \pm 1.13 \mathrm{ng} /$ $\mathrm{ml})+\mathrm{bCSP}(56.8 \pm 2.69 \mathrm{ng} / \mathrm{ml})$ contrast approached significance $(P<0 \cdot 1)$. Concentrations of PGF for BSA-treated cows were nearly twice that of bTP-1- and bCSP-treated cows.

\section{Discussion}

Infusion of highly enriched bTP-1 was effective in extending CL function in this study. In contrast, bCSP treatment had little effect upon interoestrous intervals or CL function as monitored by progesterone secretory profiles. This latter result is in contrast to those of Knickerbocker $e t$ al. (1986b) in which intrauterine infusion of bCSP extended luteal lifespan. One explanation for this discrepancy lies in the type of material used for infusion. Knickerbocker et al. (1986b) utilized conceptus secretory proteins from the first $24 \mathrm{~h}$ of incubation only, whereas in the present study a pool of conceptus secretory proteins from the first $72 \mathrm{~h}$ of culture was utilized. Although the amount of bTP-1 secreted throughout the 72-h culture period was not quantified, secretion of bTP-1 from conceptuses during the second and third 24-h periods of culture may have been lower than during the first $24 \mathrm{~h}$. If bTP-1 present in bCSP was less than that normally found in 


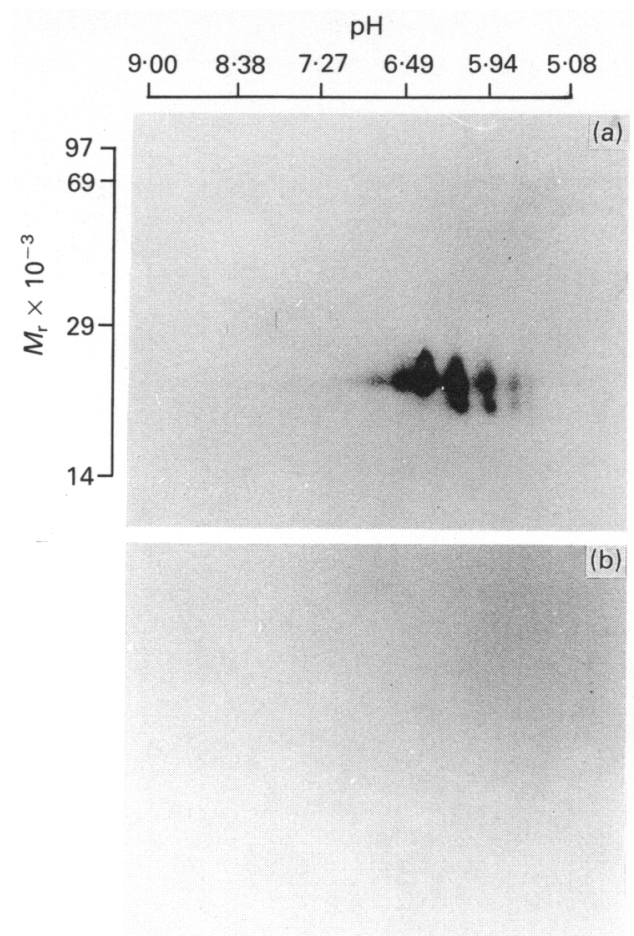

Fig. 5. Autoradiograph of 2-D SDS-PAGE of enriched bTP-1 complex ( $8 \mu \mathrm{g} / \mathrm{gel})$ transferred to nitrocellulose and immunoblotted with (a) rabbit anti-oTP-1 antiserum (1:100) or (b) normal rabbit serum.

Table 2. Characteristics of oestrous cycles for cows treated with BSA, bCSP or bTP-1 complex (least-squares means \pm s.e.m.)

\begin{tabular}{lrrrc}
\hline Response & BSA & bCSP & bTP-1 & s.e.m. \\
\hline Interoestrous interval $^{\mathrm{a}, \mathrm{b}}$ (days) & 19.5 & 21.5 & 26.0 & 1.31 \\
Interval to CL regression $^{\mathrm{b}}$ (days) & 17.7 & 18.5 & 24.0 & 1.18 \\
$\begin{array}{l}\text { Interval from CL regression to } \\
\quad \text { oestrus (days) }\end{array}$ & 1.8 & 3.2 & 2.0 & 0.54 \\
$\begin{array}{l}\text { Post-experimental interoestrous } \\
\text { interval (days) }\end{array}$ & 20.2 & 17.8 & 21.7 & 1.21 \\
\hline
\end{tabular}

aThe BSA $v s$ bCSP + bTP-1 contrast was significant $(P<0.05)$.

'The bCSP $v$ bTP-1 contrast was significant $(P<0.05)$.

the uterus during pregnancy, the treatment may not have been effective in extending the interoestrous interval due to an inadequate triggering of the antiluteolytic effect. Additionally, the bCSP treatment group received $1.5 \mathrm{mg}$ bCSP per day, representing $79 \%$ of the average protein present after culture for $24 \mathrm{~h}(1.9 \mathrm{mg})$. In contrast, bTP-1-treated animals received a daily dose of bTP-1 which had been purified from $4 \cdot 1$ conceptus culture-equivalents. The bTP-1-treated animals may therefore have been given considerably more bTP-1 than animals receiving unfractionated bCSP. Relative extension of the interoestrous interval in response to bCSP for the experiment of Knickerbocker et al. (1986b) with Holstein cows was greater than that of the present study with bTP-1 administered to Jersey cows. 


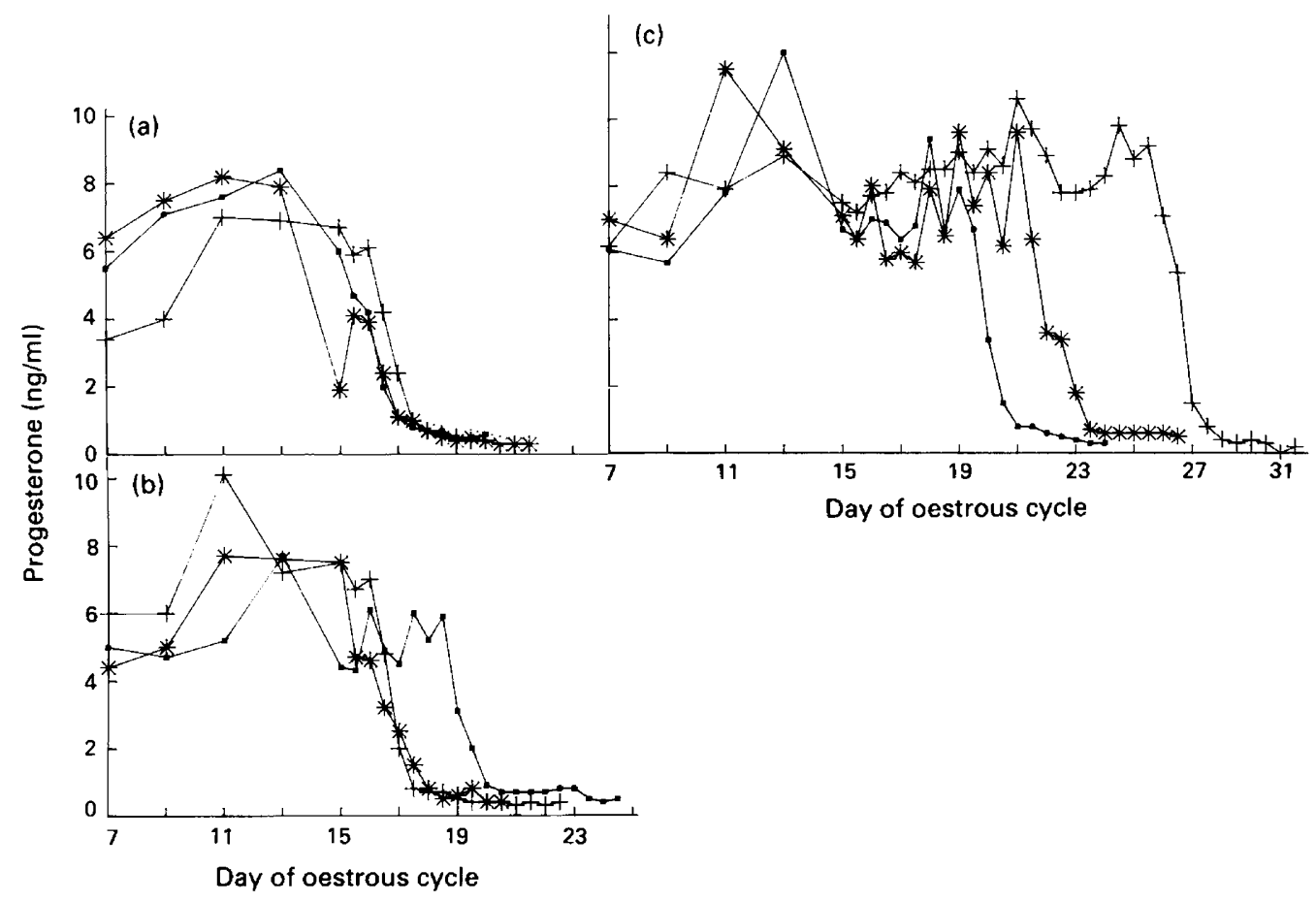

Fig. 6. Profiles of concentrations of plasma progesterone for cattle infused with (a) bovine serum albumin, (b) bCSP or (c) bTP-1 from Days 15.5 to 21 of the oestrous cycle.

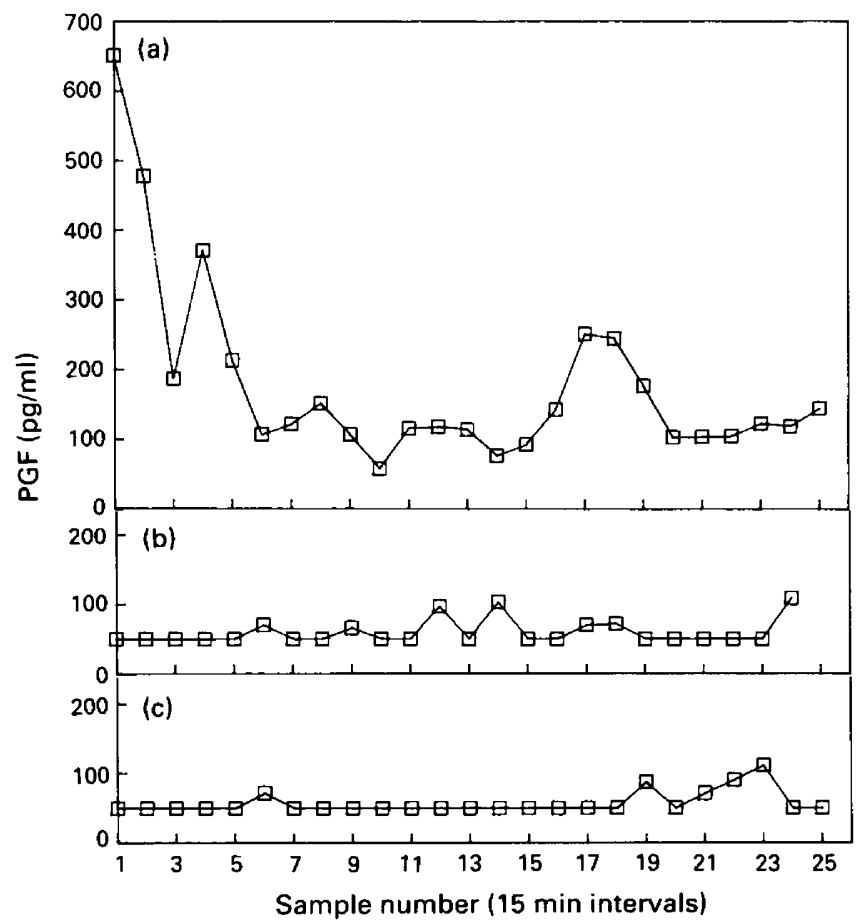

Fig. 7. Representative profiles of plasma concentrations of PGF in the vena cava for cows treated with (a) BSA, (b) bCSP or (c) bTP-1 on Day 19 after oestrus. 
The cycle extension brought about by bTP-1 treatment appears to be due to a direct effect of increasing length of the luteal phase, as shown by an increase in the period from pretreatment oestrus to when progesterone fell below $1 \mathrm{ng} / \mathrm{ml}$. This extension was not due to an increase in the follicular phase because the period from when progesterone fell below $1 \mathrm{ng} / \mathrm{ml}$ to post-treatment oestrus was not different between treatment groups. Rescue of the CL by bTP-1 is most likely the result of altered PGF- $2 \alpha$ release from the uterus since bTP-1-treated cows had altered patterns of PGF- $2 \alpha$ concentrations in vena cava plasma. It has been well established that luteolysis in cattle occurs via secretion of PGF-2 $\alpha$ from the uterus (Wolfenson et al., 1987). There is an attenuation of PGF release from cultured (Thatcher et al., 1984; Gross et al., 1988a) or perfused (Gross et al., $1988 \mathrm{~b}$ ) endometrial tissues of pregnant cattle when compared to cyclic cattle. Furthermore, Knickerbocker et al. $(1986 \mathrm{a}, \mathrm{b})$ have demonstrated that cattle which had received intrauterine infusions of bCSP had extended CL function and attenuated PGF secretion and release in response to an oestradiol challenge. The exact mechanism whereby bTP-1 attenuates PGF release is not known. It has been demonstrated that endometrial inhibitors to prostaglandin synthesizing enzymes exist and their activity is increased during pregnancy (Basu \& Kindahl, 1987; Gross et al., 1988c). Furthermoree, bCSP induces prostaglandin inhibitor activity (Gross et al., 1988a). Recently, Helmer et al. (1989) demonstrated that bTP-1 reduced secretion of PGF from explants of cyclic cattle probably via induction of an endogenous prostaglandin synthesis inhibitor(s). It is therefore possible that bTP-1 acts as an antiluteolysin by inducing inhibitors to prostaglandin synthesizing enzymes in the uterus. It is evident that similar mechanisms for preventing luteal regression exist in the sheep and cow. The antiluteolytic molecules responsible for this event, bTP-1 and oTP-1, have extensive amino acid sequency homology with each other and interferon- $\alpha$ (Imakawa et al., 1989) and regulate PGF-2 $\alpha$ secretion. Nevertheless, there are some differences between sheep and cattle in the dynamics of PGF-2 $\alpha$ secretion in early pregnancy (see Thatcher $e t$ al., 1986, for review) with secretion being much more suppressed in cattle than sheep. The ability of bTP-1 to induce an intracellular endometrial prostaglandin synthetase inhibitor (Helmer et al., 1989) may account for this suppression in early pregnancy. Whether oTP-1 has a similar effect has not been tested. However, Salamonsen et al. (1988) demonstrated that oTP-1 suppresses PGF-2 $\alpha$ and PGE-2 secretion from cultured endometrial cells of sheep.

We thank Dr T. G. Kennedy for the generous gift of PGF-2 $\alpha$ antiserum; Dr M. Drost and Dr S. Norman for technical assistance; and DuPont Co. for supplying the h.p.l.c. GF-250 gel filtration column. This study was supported in part by USDA Grant 85-CRCR-1-1871. This is Journal Series No. 9491 of the Florida Agricultural Experiment Station.

\section{References}

Anthony, R.V., Helmer, S.D., Sharif, S.F., Roberts, R.M., Hansen, P.J., Thatcher, W.W. \& Bazer, F.W. (1988) Synthesis and processing of ovine trophoblast protein- 1 and bovine trophoblast protein- 1 , conceptus secretory proteins involved in the maternal recognition of pregnancy. Endocrinology 123, 1274-1280.

Bartol, F.F., Roberts, R.M., Bazer, F.W., Lewis, G.S., Godkin, J.D. \& Thatcher, W.W. (1985) Characterization of proteins produced in vitro by periattachment bovine conceptuses. Biol. Reprod. 32, 681-693.

Basu, S. \& Kindahl, H. (1987) Inhibitor of prostaglandin biosynthesis in the bovine endometrium during estrous cycle and early pregnancy. Theriogenology 27, 212226.

Betteridge, K.J., Randall, G.C.B., Eaglesome, M.D. \& Sugden, E.A. (1984) The influence of pregnancy of $\mathrm{PGF}_{2} \alpha$ secretion in cattle. I, Concentrations of 15-keto-13,14-dihydro-prostaglandin $\mathrm{F}_{2} \alpha$ and progesterone in peripheral blood of recipients of transferred embryos. Anim. Reprod. Sci. 7, 195-216.

Dalla Porta, M.A. \& Humblot, P. (1984) Effect of conceptus removal and intrauterine administration of conceptus tissue on luteal function in the cow. Reprod. Nutr. Develop. 24, 529-541.

Dunbar, B.S. (1987) Two-Dimensional Electrophoresis and Immunological Techniques. Plenum Press, New York.

Godkin, J.D., Bazer, F.W., Thatcher, W.W. \& Roberts, R.M. (1984) Proteins released by Day 15-16 conceptuses prolong luteal maintenance when introduced into the uterine lumen of cyclic ewes. J. Reprod. Fert. 71, 57-64.

Gross, T.S., Plante, C., Thatcher, W.W., Hansen, P.J., Helmer, S.D. \& Putney, D.J. (1988a) Secretory 
proteins of the bovine conceptus alter endometrial prostaglandin and protein secretion in vitro. Biol. Reprod. 39, 977-987.

Gross, T.S., Thatcher, W.W., Hansen, P.J. \& Lacroix, M.C. (1988b) Prostaglandin secretion by perifused bovine endometrium: secretion towards the myometrial and luminal sides at day 17 post-estrus as altered by pregnancy. Prostaglandins 35, 343-357.

Gross, T.S., Thatcher, W.W., Hansen, P.J., Johnson, J.W. \& Helmer, S.D. (1988c) Presence of an intracellular endometrial inhibitor of prostaglandin synthesis during early pregnancy in the cow. Prostaglandins 35, 359-378.

Guilbault, L.A., Thatcher, W.W., Drost, M. \& Hopkins, S.M. (1984) Source of $F$ series prostaglandins during the early postpartum period in cattle. Biol. Reprod. 31, 879-887.

Hansen, P.J. \& Newton, G.R. (1988) Binding of immunoglobulins to the major progesterone-induced proteins secreted by the sheep uterus. Archs Biochem. Biophys. 260, 208-217.

Helmer, S.D., Hansen, P.J., Anthony, R.V., Thatcher, W.W., Bazer, F.W. \& Roberts, R.M. (1987) Identifcation of bovine trophoblast protein-1, a secretory protein immunologically related to ovine trophoblast protein-1. J. Reprod. Fert. 79, 83-91.

Helmer, S.D., Hansen, P.J. \& Thatcher, W.W. (1988) Differential glycosylation of the components of the bovine trophoblast protein-1 complex. Molec. cell. Endocr. 58, 103-107.

Helmer, S.D., Gross, T.S., Hansen, P.J. \& Thatcher, W.W. (1989) Bovine trophoblast protein-1 complex alters endometrial protein and prostaglandin secretion and induces an intracellular inhibitor of prostaglandin synthesis in vitro. J. Reprod. Fert. 87, (in press).

Imakawa, K., Hansen, T.R., Malathy, P.V., Anthony, R.V., Polites, H.G., Marotti, K.R. \& Roberts, R.M. (1989) Molecular cloning and characterization of complementary deoxyribonucleic acids corresponding to bovine trophoblast protein-1: a comparison with ovine trophoblast protein-1 and bovine interferon-alI. Molec. Endocr. 3, 127-139.

Kennedy, T. G. (1985) Evidence for the involvement of prostaglandins throughout the decidual cell reaction in the rat. Biol. Reprod. 33, 140-146.

Knickerbocker, J.J., Thatcher, W.W., Bazer, F.W., Barron, D.H. \& Roberts, R.M. (1986a) Inhibition of uterine prostaglandin $F_{2} \alpha$ production by bovine conceptus secretory proteins Prostaglandins 31, 777-793.

Knickerbocker, J.J., Thatcher, W.W., Bazer, F.W., Drost, M., Barron, D.H., Fincher, K.B. \& Roberts, R.M. (1986b) Proteins secreted by Day 16 to 18 conceptuses extend corpus luteum function in cows. J. Reprod. Fert. 77, 381-391.

Knickerbocker, J.J., Thatcher, W.W., Foster, D.B., Wolfenson, D., Bartol, F.F. \& Caton, D. (1986c) Uterine prostaglandin and blood flow responses to estradiol-17 $\beta$ in cyclic cattle. Prostaglandins 31, $757-776$.

Laemmli, U.K. (1970) Cleavage of structural protein during the assembly of the head of bacteriophase T-4. Nature, Lond. 227, 680-685.

Macmillan, K.L., Taufa, V.K., Barnes, D.R., Day, A.M. \& Henry, R. (1988) Detecting oestrus in synchronized heifers using tailpaint and an aerosol raddle. Theriogenology 30, 1099-1114.

Malayer, J.R., Hansen, P.J. \& Buhi, W.C. (1988) Effect of day of the oestrous cycle, side of the reproductive tract and heat shock on in-vitro protein secretion by bovine endometrium. J. Reprod. Fert. 84, 567-578.

Northey, D.L. \& French, L.R. (1980) The effect of embryo removal and intrauterine infusion of embryonic homogenates on the lifespan of the bovine corpus luteum. J. Anim. Sci. 50, 298-302.

Roberts, R.M., Baumbach, G.A., Buhi, W.C., Denny, J.B., Fitzgerald, L.A., Babelyn, S.F. \& Horst, M.N. (1984) Analysis of membrane polypeptides by twodimensional polyacrylamide gel electrophoresis. In Molecular and Chemical Characterization of Membrane Receptors, pp. 61-113. Eds C. J. Venter \& L. C. Harrison. A. R. Liss, Inc., New York.

Salamonsen, L.A., Stuchbery, S.J., O'Grady, C.M., Godkin, J.D. \& Findlay, J.K. (1988) Interferon- $\alpha$ mimics effects of ovine trophoblast protein 1 on prostaglandin and protein secretion by ovine endometrial cells in vitro. J. Endocr. 117, R I-R4.

SAS (1985) SAS User's Guide: Statistics. SAS Institute Inc., Cary, NC.

Sears, P.M., Paape, M.J., Pearson, R.E. \& Gwazdauskas, F.C. (1978) Comparison between tail vein and jugular vein cannulation in cattle. J. Dairy Sci. 61, 974-979.

Smith, P.K., Krohn, R.I., Hermanson, G.T., Mallia, A.K., Gartner, F.H., Provenzano, M.D., Fujimoto, E.K., Goeke, N.M., Olson, B.J. \& Klenk, D.C. (1985) Measurement of protein using bicinchoninic acid. Analyt. Biochem. 150, 7685.

Thatcher, W.W., Bartol, F.F., Knickerbocker, J.J., Curl, J.S., Wolfenson, D., Bazer, F.W. \& Roberts, R.M. (1984) Maternal recognition of pregnancy in cattle. $J$. Dairy Sci. 67, 2797-2811.

Thatcher, W.W., Bazer, F.W., Sharp, D.C. \& Roberts, R.M. (1986) Inter-relationships between uterus and conceptus to maintain corpus luteum function in early pregnancy: sheep, cattle, pigs and horses. $J$. Anim. Sci. 62 (Suppl. 2), 25-46.

Wolfenson, D., Thatcher, W.W., Bartol, F.F. \& Knickerbocker, J.J. (1987) Effect of uterine luminal perfusion of $\mathrm{PGF}_{2} \alpha$ and $\mathrm{PGE}_{2}$ on uterine vasomotor response and $\mathrm{PGF}_{2} \alpha$ output in cyclic cattle. Anim. Reprod. Sci. 14, 103-113.

Wray, W., Boulikas, T., Wray, V.P. \& Hancock, R. (1981) Silver staining of proteins in polyacrylamide gels. Analyt. Biochem. 118, 197-203.

Received 23 November 1988 